Age and gender features of the correlation between the emotional evaluation of commercials and the intelligence

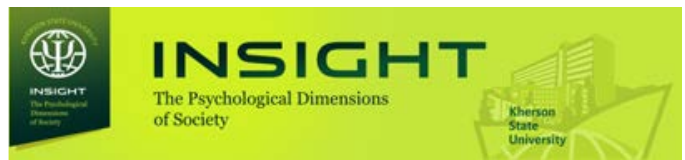

DOI: $10.32999 / 2663-970 X / 2021-6-4$

Link article (Style APA): Kolly-Shamne, A. V., \& Tokareva, N. M. (2021). Age and gender features of the correlation between the emotional evaluation of commercials and the intelligence indicators of high school and university students. Insight: the psychological dimensions of society, 6, 41-55. DOI: $10.32999 / 2663-970 X / 2021-6-4$

Link article (Style DSTU 8302: 2015): Kolly-Shamne, A. V., Tokareva, N. M. Age and gender features of the correlation between the emotional evaluation of commercials and the intelligence indicators of high school and university students. Insight: the psychological dimensions of society, 2021, 6, 41-55. DOI: $10.32999 / 2663-970 X / 2021-6-4$

UDC [159.922.6+159.922.1]:159.922.8

\title{
Age and gender features of the correlation between the emotional evaluation of commercials and the intelligence indicators of high school and university students
}

\author{
Вікові та гендерні особливості зв'язку емоційної оцінки рекламних \\ відеороликів і показників інтелекту учнів старших класів та студентів
}

Received: October 13, 2021

\author{
Kolly-Shamne Anzhelika Volodymyrivna, \\ Doctor of Psychological Sciences, Professor, \\ Department of General and Age Psychology, \\ Kryvyi Rih State Pedagogical University, \\ Ukraine \\ shamne@urk.net \\ https://orcid.org/0000-0003-1541-6079 \\ Tokareva Natalya Mykolayivna, \\ Doctor of Psychological Sciences, Professor, \\ Department of General and Age Psychology, \\ Kryvyi Rih State Pedagogical University, \\ Ukraine \\ tokareva152681@gmail.com \\ https://orcid.org/0000-0003-1428-3729
}

\section{Abstract}

The article is devoted to the empirical study of one of the dimensions of the problem of the relationship between intelligence and emotional evaluation of personality. The aim of this article is to investigate the age and gender characteristics of verbal, mathematical, spatial intelligence in adolescence and youths, as well as to establish a correlation with the characteristics of emotional evaluation of commercials by high school and university students of different genders. The study focused on determining the age and gender
Accepted: November 11, 2021

Коллі-Шамне Анжеліка Володимирівна, доктор психологічних наук, професор кафедра загальної та вікової психології, Криворізький державний педагогічний університет, Україна, shamne@urk.net https://orcid.org/0000-0003-1541-6079

Токарева Наталя Миколаївна, доктор психологічних наук, професор кафедра загальної та вікової психології, Криворізький державний педагогічний університет, Україна, tokareva152681@gmail.com https://orcid.org/0000-0003-1428-3729

\section{Анотація}

Стаття присвячена емпіричному дослідженню одного з вимірів проблеми взаємозв'язку інтелекту та емоційної оцінки особистості. Метою статті $€$ дослідження вікових та ґендерних особливостей вербального, математичного, просторового інтелекту в підлітковому та юнацькому віці, а також встановлення зв'язку з особливостями емоційної оцінки рекламних роликів учнями та студентами різної статі. Означене зорієнтувало дослідження на такі проблемні напрямки: встановлення вікових 
characteristics of intelligence indices of high school students aged 15-17 ( $\mathrm{N}=47)$ and university students aged 19-21 ( $\mathrm{N}=49$ ); and determining the relationship between the verbal, mathematical, and spatial intelligence of the two samples' respondents (adolescents and young people, boys and girls), and their emotional evaluation of the commercials. Methods. In order to solve research questions, two approaches are used: R. Amthauer's "Test of the Structure of Intelligence" and C. Osgood's semantic differential method. Results. In contrast to high school students, university students have a higher level of development of verbal and mathematical intelligence. A higher level of development of verbal intelligence in girls and a higher level of development of spatial intelligence in boys were stated. Significant correlations between the emotional evaluation of commercials and gender and age characteristics of intellectual abilities have been identified. The independent variable "gender" has a higher value than the independent variable "age", according to the mathematical and spatial intelligence of boys and girls in their advertising evaluation. Music commercials with actors, a storyline, and elements of drama, as well as videos with computer special effects, were found to be the most entertaining to the respondents.

Keywords: cognitive abilities, verbal intelligence, mathematical intelligence, spatial intelligence, advertising, semantic differential.

\section{Introduction}

For decades, intelligence has been examined as one of the important factors that shapes the psychological image of the person in the psychology of individual differences. Despite the debate over the definition of intelligence, most modern researchers have considered intelligence to be a set of cognitive sphere traits that can be traced in many forms of cognitive activity.

Despite the existing and growing number of studies in this field, many questions remain open, in particular: the problem of assessing general abilities, which are most often assessed by intelligence (Breit et al., 2020; Kurt, 2019), the relationship of intelligence with physical and mental health (Yakovleva, 2019; Latvala et al., 2016; Mollon et al., 2018), etc. A significant number of controversial issues are due to the fact that, in psychology, there is a tradition of considering intelligence separately from other personal characteristics. The gap between the intellectual and personal components, which та ґендерних особливостей індексів інтелекту учнів старших класів віком 15-17 років $(\mathrm{N}=47)$ та студентів закладу вищої освіти віком 19-21 років $(\mathrm{N}=49)$; визначення зв'язку вербального, математичного та просторового інтелекту респондентів двох вибірок (підлітки-юнаки, хлопці-дівчата) з емоційною оцінкою ними рекламних відеороликів. Методи. Розв'язування дослідницьких завдань передбачало використання двох методик: “Тесту структури інтелекту” Р. Амтхауера та методики семантичного диференціалу Ч. Осгуда. Результати. Встановлено більш високий рівень розвитку вербального та математичного інтелекту у студентів порівняно з учнями старших класів. Констатовано більш високий рівень розвитку вербального інтелекту у дівчат і більш високий рівень розвитку просторового інтелекту у хлопців. Виявлено значущі кореляційні взаємозв'язки емоційної оцінки рекламних роликів з гендерними та віковими особливостями інтелектуальних здібностей. Значення незалежної змінної "стать" є більш сильним порівняно з незалежною змінною “вік”, що з'ясовано переважно у зв'язку математичного та просторового інтелекту хлопців і дівчат з оцінкою ними реклами. Визначено, що найбільш привабливими для респондентів є музичні рекламні ролики за участі акторів, наявністю сюжетної лінії та елементами драматургії, а також ролики з використанням комп'ютерних спецефектів.

Ключові слова: когнітивні здібності, вербальний інтелект, математичний інтелект, просторовий інтелект, реклама, семантичний диференціал.

\section{Вступ}

Впродовж багатьох десятиліть інтелект традиційно вивчається в рамках психології індивідуальних відмінностей як одна з істотних характеристик, що визначає психологічний образ людини. Не дивлячись на суперечки у визначенні інтелекту, більшість сучасних дослідників виходять з розуміння інтелекту як сукупності характеристик когнітивної сфери, що відстежується в різних формах пізнавальної діяльності.

Незважаючи на вже існуючу i зростаючу кількість досліджень в цій сфері, багато питань залишається відкритими, зокрема: проблема оцінки загальних здібностей, які найчастіше оцінюються за допомогою інтелекту (Breit et al., 2020; Kurt, 2019), зв'язку інтелекту з фізичним і психічним здоров'ям

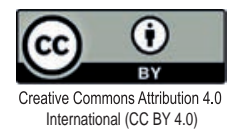




\section{Age and gender features of the correlation between the emotional evaluation of commercials and the intelligence indicators of high school and university students}

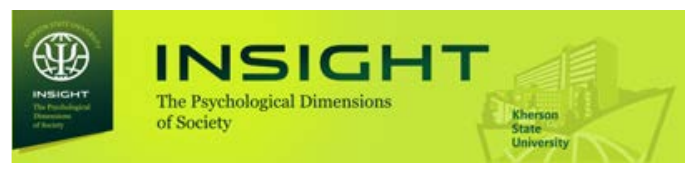

stems from the Wurtzburg school's tradition of intellectualism, has been transformed into a problem of the relationship between affect and intelligence, which remains one of the most controversial topics in modern psychology.

The debatability of this problem is determined by the fact that some researchers confirm the relationship between intelligence and personality (Anan'ev, 1977; Ivanova, 2013; Rubinshtejn, 1999; Brand et al., 1991), while others deny it (Eysenck, 1996; Rusalov \& Dudin, 1995). Adhering to the first of these positions, we rely on the idea of Anan'ev (1977) that the features of the affective sphere (needs, interests, attitudes) determine the activity of the intelligence, but they themselves depend on the degree of objectivity of the individual to reality, the experience of knowledge of the world, and the general development of intelligence. The content of the unity of the intellectual and the personal is contained in the unity of their psychological mechanisms, in which there is no "impersonal intellect" and "nonintellectual personality" (Ponomarev, 1983). In the context of a systems approach, it is not only about the relationship and influence of cognitive and affective spheres of personality, but also about the origin of their interaction of special personal and intellectual qualities (Ivanova, 2013), which, becoming the property of character, begin to define not only the intelligence as such but also the personality as a whole (Rubinshtejn, 1999).

Through the projection of intelligence on the emotional perception of objects in the outside world, in particular commercials, which are a conglomeration of verbal, visual, and audiovisual components and tools, we attempted to investigate the current problem of the relationship between intelligence and the affective sphere of personality in the context of the outlined provisions. The combination of these approaches assures the rational and emotional impact of advertising is consistent, and it captures the interaction between a person's affective attitude toward the advertising message, emotions and feelings, and cognitive information processing processes.

We were unable to find data on such an important aspect of the relationship between intelligence and personality as the relationship
(Яковлева, 2019; Latvala et al., 2016; Mollon et al., 2018) тощо. Значна кількість дискусійних питань пов'язана з тим, що у психології склалася традиція розглядати інтелект окремо від інших особистісних характеристик. Розрив інтелектуального і особистісного компонентів, який виходить 3 традиції інтелектуалізму Вюрцбурзької школи, трансформувався у проблему взаємозв'язку афекту та інтелекту, яка залишається однією з найбільш суперечливих у сучасній психології.

Дискусійність цієї проблеми визначається тим, що частина дослідників підтверджує взаємозв'язок інтелекту і особистості (Ананьев, 1977; Иванова, 2013; Рубинштейн, 1999; Brand et al., 1991), інша ж його заперечує (Eysenck, 1996; Русалов \& Дудин, 1995). Дотримуючись першої з цих позицій, ми спираємось на ідею Б. Ананьєва про те, що особливості афективної сфери (потреби, інтереси, установки) визначають активність інтелекту, але самі вони залежать від міри об'єктивності ставлень особистості до дійсності, досвіду пізнання світу і загального розвитку інтелекту (Ананьєв, 1977). Зміст єдності інтелектуального і особистісного укладено в єдності їх психологічного механізму, в якому немає "безособистісного інтелекту" і “неінтелектуальної особистості" (Пономарев, 1983: 22). У контексті системного підходу мова йде не тільки про взаємозв'язок і вплив одна на одну когнітивної та афективної сфер особистості, а й про походження при їх взаємодії особливих особистісно-інтелектуальних якостей (Иванова, 2013), які, “перетворюючись у властивості характеру, починають визначати не тільки інтелект як такий, але і особистість в цілому" (Рубинштейн, 1999: 629).

Актуальну, в контексті окреслених положень, проблему взаємозв'язку інтелекту та афективної сфери особистості ми намагалися дослідити через проєкцію інтелекту на емоційне сприйняття об’єктів зовнішнього світу, зокрема, рекламних відеороликів, які $\epsilon$ конгломератом вербальних, візуальних i аудіовізуальних компонентів та засобів. Сукупність цих засобів забезпечує єдність раціонального та емоційного впливу реклами та утілює взаємозв'язок між афективним ставленням людини до рекламного повідомлення, 
between the emotional evaluation of advertising and the age and gender characteristics of modern youths' intelligence, according to the findings of the theoretical analysis. As a result, the findings will add to the growing body of knowledge about the relationship between the cognitive and affective worlds of personality, particularly between adolescence and youths.

Hypotheses. H1. In terms of age and gender, the intelligence indices of high school students and university students differ. H2. There is a correlation between the age characteristics of high school and university students' intelligence and the differences in their emotional evaluation of various forms of commercials. H3. There is a correlation between the gender characteristics of intelligence indicators of boys and girls aged 15-20 years emotional evaluation of various forms of commercials.

The aim of the experimental research was to study the age and gender characteristics of intelligence and their relationship with the emotional evaluation of commercials in adolescence and youths.

\section{Methodology and Methods}

The initial theoretical and methodological perspective of the study is the conceptual idea of the unity of rational thinking, perception, and affect/emotion in providing mental and perceptual human activity as a consumer of advertising, which focuses on modern cognitive science (Di Paolo \& Thompson, 2014; Panksepp, 2000; Vorobyova, 2017; Zlatev, 2016). With this in mind, intelligence study methodology was centered on the concepts of personal and procedural methods. The first considers human as a system of personal and intellectual property ratios, whereas the second emphasizes intelligence as a procedural characteristic (Akimova, 1999), understanding it "not as a quasistable fact, but as a structured set of intellectual operations" (Meily, 1981: 30).

We defined intelligence as a "set of ways ofanintellectualapproach to theworld" (Sternberg, 1988), as a form of interprocess and metacognitive organization and reorganization of individual mental experience (Holodnaya, 2002), with different modalities depending on specific tasks iї емоціями та почуттями, когнітивними процесами переробки інформації.

За результатами теоретичного аналізування нам не вдалося знайти даних щодо такого важливого аспекту взаємозв'язку інтелекту і особистості, як зв'язок емоційної оцінки реклами та вікових і гендерних особливостей інтелекту сучасної молоді. Таким чином, представлені результати доповнять собою проблемне поле взаємозв'язку когнітивної та афективної сфер особистості, зокрема, в період підліткового та юнацького віку.

Гіпотези: 1. Наявні певні вікові та ґендерні відмінності індексів інтелекту учнів старших класів та студентів. 2. Існує зв'язок вікових особливостей інтелекту учнів та студентів з особливостями емоційного оцінювання ними рекламних відеороликів різного типу. 3. Існує зв'язок гендерних особливостей показників інтелекту 3 емоційною оцінкою рекламних відеороликів різного типу юнаками та дівчатами у віці 15-20 років.

Мета експериментального дослідження полягала у досліджені вікових та гендерних особливостей інтелекту та їх взаємозв'язку з емоційною оцінкою рекламних відеороликів у підлітковому та юнацькому віці.

\section{Методологія та методи}

Вихідним теоретико-методологічним положенням дослідження $\epsilon$ концептуальна ідея єдності раціонального мислення, перцепції та афекту/емоції в забезпеченні розумової та перцептивної діяльності людини як споживача реклами, на якій акцентують увагу представники сучасної когнітивної науки (Di Paolo \& Thompson, 2014; Panksepp, 2000; Vorobyova, 2017; Zlatev, 2016). 3 урахуванням цього, методологія дослідження інтелекту базувалася на ідеях особистісного та процесуального підходів. Перший розглядає людину в системі співвідношення особистісних і інтелектуальних властивостей, другий наголошує на розумінні інтелекту як процесуальної характеристики (Акимова, 1999), на розумінні його “не як квазістабільної даності, а як структурованої сукупності інтелектуальних активностей" (Meily, 1981: 30).

Інтелект ми розуміли як “набір способів інтелектуального підходу до навколишнього 


\section{Age and gender features of the correlation between the emotional evaluation of commercials and the intelligence indicators of high school and university students}

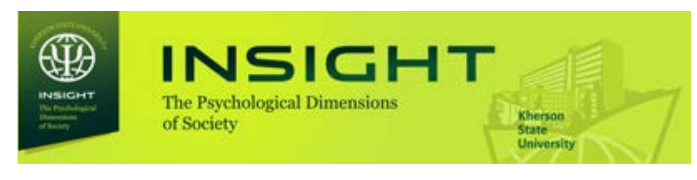

and features of the context in which they are carried out (Smul'son, 2003).

Participants. Respondents were divided into two groups (a total of 96 respondents, 47 girls, and 49 boys) for the study ( $M=17.25, \sigma=1.54)$ : 1) 47 high school students aged 15-17 years of Kryvyi Rih Metallurgical Lyceum No 16 (Kryvyi Rih, Ukraine) from 10-11th grades; 2) 49 full-time third-year university students aged 19-21 years of National University of Life and Environmental Sciences of Ukraine, Faculty of Humanities and Pedagogy (Kyiv, Ukraine).

Procedure and instruments. Two approaches were used to test all of the participants.

1) The "Intelligence Structure Test" by R. Amthauer (Amthaueret al., 1999) was used to determine intelligence indicators. The test allows to diagnose verbal (subtests 1-5), mathematical (subtests 6-7), and spatial (subtests 8-9) intelligence. The intellectual abilities of senior adolescence (high school students of 10-11th grades) and youths (the third-year university students) (independent variable - age) were compared in the first stage, and the intellectual abilities of the same respondents - girls and boys were compared in the second stage (independent variable - gender).

2) The semantic differential method of $\mathrm{Ch}$. Osgood was used to determine the emotional evaluation of commercials. For this study, five different types of promotional videos were chosen: "Otryvin" animated video based on computer graphics and special effects; musical video "Pantene" with the participation of actors with behind-the-scenes narration; music video of the information type "Khilak-forte" without the participation of actors with behind-the-scenes narration and elements of animation; "Samsung" commercial, based on the movements of tennis star M. Sharapova; plot music video "Raiffeisen Bank" with actors and behind-the-scenes narration, built on the basis of video stories and micro-dialogues between actors. A detailed description of these commercials, their content, selection and evaluation procedure is described in the article (Shamne et al., 2019), which presents the results of the first stage of the study.

The expediency of using the method of semantic differential for the evaluation of advertising світу" (Sternberg, 1988: 275), як форму організації та реорганізації індивідуального ментального досвіду (Холодная, 2002), що має міжпроцесуальну і метакогнітивну природу, різні модальності залежно від конкретних задач і особливостей контексту, в якому вони здійснюються (Смульсон, 2003: 11).

Учасники. У дослідженні взяли участь респонденти, об'єднані у дві вибіркові сукупності (всього 96 респондентів, з них 47 дівчат та 49 юнаків) ( $M=17.25, \sigma=1.54): 1) 47$ учнів 10-11 класів Криворізького металургійного ліцею № 16 віком 15-17 років (м. Кривий Ріг, Україна); 2) 49 студентів денного відділення 3-го курсу гуманітарно-педагогічного факультету Національного університету біоресурсів та природокористування України віком 19-21 років (м. Київ, Україна).

Процедура та інструменти. Всі досліджувані проходили тестування за двома методиками.

1) Показники інтелекту визначалися за допомогою "Тесту структури інтелекту" P. Амтхауера (Amtchauer et al., 1999), який дозволяє діагностувати вербальний (субтести 1-5), математичний (субтести 6-7), просторовий (субтести 8-9) інтелект. На першому етапі порівняно інтелектуальні здібності респондентів старшого підліткового віку (учні 10-11-х класів) та юнацького віку (студенти 3-го курсу 3В0) (незалежна змінна - вік), а на другому - інтелектуальні здібності тих самих респондентів - дівчат та хлопців у віці 15-21 років (незалежна змінна - стать).

2) Емоційну оцінку рекламних роликів визначено за допомогою методики семантичного диференціалу Ч. Осгуда. Для оцінки було відібрано п'ять типів рекламних відеороликів: мультиплікаційний ролик "Отривін” на основі комп'ютерної графіки та спецефектів; музичний ролик "Пантін" за участю акторів з закадровим дикторським текстом; музичний ролик інформаційного типу “Хілак-форте" без участі акторів з закадровим дикторським текстом та елементами анімації; рекламний ролик "Samsung", побудований на основі рухів зірки великого тенісу М. Шарапової; сюжетний музичний ролик “Банк Райфайзен” з акторами та закадровим дикторським текстом, побудований на основі відео-історій та мікро-діалогів

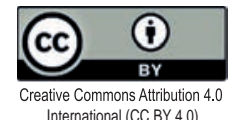


products has been proven in the works of many psychologists, marketers, and advertisers (Plichtová, 2002). The method allowed us to quantitatively and qualitatively index the results of measuring the emotional attitude of respondents to the proposed objects of advertising and to record the uniqueness of their subjective values, due to their individual life experiences.

Statistical analysis. The obtained results were processed using the statistical package SPSS for Windows v. 15.0.0: descriptive statistics, correlation analysis. The Student's t-test was calculated to establish differences between age and gender samples.

\section{Results}

Tables 1-2 showed the findings of diagnostics in groups of high school and university students based on the R. Amthauer test: descriptive statistics (mean, etc.) (Table 1) and differences in verbal, mathematical, and spatial intelligence indices of these age groups based on the Student's t-test (Table 2).

Significant differences between these groups were found in terms of verbal and mathematical intelligence. Third-year university students, in particular, had a higher level of verbal (.05) and mathematical (.05) ability development. There were no significant differences between the tested groups' indices of spatial intelligence development (Tabl. 2). між акторами. Детальний опис цих рекламних роликів, їх зміст, процедуру відбору та оцінки описано у публікації (Шамне та ін., 2019), у якій представлено результати першого етапу дослідження.

Доцільність використання методу семантичного диференціалу для оцінки рекламної продукції доведена у працях багатьох психологів, маркетологів та рекламістів (Plichtová, 2002: 81). Метод дозволив нам кількісно та якісно індексувати результати вимірювання емоційного ставлення респондентів до запропонованих об'єктів реклами і зафіксувати унікальність їх суб'єктивних значень, зумовлену їх індивідуальним життєвим досвідом.

Статистичне аналізування. Отримані результати оброблялися за допомогою статистичного пакета SPSS for Windows v. 15.0.0: описова статистика, кореляційний аналіз. Для встановлення відмінностей між віковими та ґендерними вибірками розраховано t-критерій Стьюдента.

\section{Результати}

У таблицях 1-2 представлені результати діагностики за тестом Р. Амтхауера у групах учнів та студентів: описові статистики (середні значення тощо) (табл. 1) і відмінності індексів вербального, математичного та просторового інтелекту цих вікових груп за критерієм Стьюдента (табл. 2).

Table 1. Descriptive statistics of 10-11th grade high school students $(\mathrm{N}=47)$ and 3rd-year university students' $(\mathrm{N}=49$ ) intelligence indices (according to the method of R. Amthauer)

Таблиця 1. Описові статистики індексів інтелекту учнів 10-11-х класів (N=47) та студентів 3-го курсу (N=49) (за методикою Р. Амтхауера)

\begin{tabular}{|c|c|c|c|c|c|c|}
\hline \multirow{2}{*}{$\begin{array}{l}\text { Parameters } \\
\text { Параметри }\end{array}$} & \multicolumn{2}{|c|}{$\begin{array}{c}\text { Verbal intelligence } \\
\text { Вербальний інтелект }\end{array}$} & \multicolumn{2}{|c|}{$\begin{array}{l}\text { Mathematical intelligence } \\
\text { Математичний інтелект }\end{array}$} & \multicolumn{2}{|c|}{$\begin{array}{c}\text { Spatial intelligence } \\
\text { Просторовий інтелект }\end{array}$} \\
\hline & $\begin{array}{c}\text { High school } \\
\text { students } \\
\text { Учні } \\
\end{array}$ & $\begin{array}{c}\text { University } \\
\text { students } \\
\text { Студенти }\end{array}$ & $\begin{array}{c}\text { High school } \\
\text { students } \\
\text { Учні } \\
\end{array}$ & $\begin{array}{l}\text { University } \\
\text { students } \\
\text { Студенти } \\
\end{array}$ & $\begin{array}{l}\text { High school } \\
\text { students } \\
\text { Учні }\end{array}$ & $\begin{array}{c}\text { University } \\
\text { students } \\
\text { Студенти }\end{array}$ \\
\hline $\begin{array}{l}\text { Sum, } \Sigma \\
\text { Сума, } \Sigma\end{array}$ & 2622 & 2866 & 1037 & 1222 & 1205 & 1263 \\
\hline $\begin{array}{l}\text { Mean, Mx } \\
\text { Середні показники, } \\
\text { Мx }\end{array}$ & 55.7 & 58.9 & 21.06 & 25 & 25.6 & 25.9 \\
\hline $\begin{array}{l}\text { Dispersion, Dx } \\
\text { Середні показники, } \\
\text { Mx }\end{array}$ & 310.9 & 437,37 & 48.5 & 37.9 & 62.4 & 57.9 \\
\hline $\begin{array}{l}\text { Standard Deviation, } \Sigma \mathrm{x} \\
\text { Ст. відхилення, } \Sigma \mathrm{x}\end{array}$ & 17.6 & 20.9 & 6.9 & 6.1 & 7.9 & 7.6 \\
\hline
\end{tabular}


Age and gender features of the correlation between the emotional evaluation of commercials and the intelligence indicators of high school and university students

Table 2. Differences in intelligence indices of high school students $(\mathrm{N}=47)$ and university students $(\mathrm{N}=49)$ (according to the method of R. Amthauer)

Таблиця 3. Описові статистики індексів інтелекту у юнаків (N=49) та дівчат (N=47)

(за методикою Р. Амтхауера)

\begin{tabular}{|c|c|c|c|}
\hline \multirow{2}{*}{$\begin{array}{l}\text { Intelligence indicators } \\
\text { Показники інтелекту }\end{array}$} & \multicolumn{2}{|c|}{$\begin{array}{c}\text { Mean indicators } \\
\text { Середні показники }\end{array}$} & \multirow{2}{*}{$\begin{array}{c}\text { Student's t-test } \\
\text { t-критерій Стьюдента }\end{array}$} \\
\hline & $\begin{array}{c}\text { High school students } \\
\text { Учні }\end{array}$ & $\begin{array}{c}\text { University students } \\
\text { Студенти }\end{array}$ & \\
\hline $\begin{array}{l}\text { Verbal } \\
\text { Вербальний }\end{array}$ & 55.7 & 58.9 & $\mathrm{t}=2.031^{*}$ \\
\hline $\begin{array}{l}\text { Mathematical } \\
\text { Математичний }\end{array}$ & 21.06 & 25.0 & $\mathrm{t}=1.988^{*}$ \\
\hline $\begin{array}{l}\text { Spatial } \\
\text { Просторовий }\end{array}$ & 25.6 & 25.9 & $\mathrm{t}=.078$ \\
\hline
\end{tabular}

Note: $* \mathrm{p}<.05$

Примітка: * $\mathrm{p}<.05$

Table 3. Descriptive statistics of intelligence indices in boys $(\mathrm{N}=49)$ and girls $(\mathrm{N}=47)$ (according to the method of R. Amthauer)

Таблиця 3. Описові статистики індексів інтелекту у юнаків (N=49) та дівчат (N=47) (за методикою Р. Амтхауера)

\begin{tabular}{|c|c|c|c|c|c|c|}
\hline \multirow{2}{*}{$\begin{array}{l}\text { Parameters } \\
\text { Параметри }\end{array}$} & \multicolumn{2}{|c|}{$\begin{array}{c}\text { Verbal intelligence } \\
\text { Вербальний інтелект }\end{array}$} & \multicolumn{2}{|c|}{$\begin{array}{c}\text { Mathematical intelligence } \\
\text { Математичний } \\
\text { інтелект }\end{array}$} & \multicolumn{2}{|c|}{$\begin{array}{c}\text { Spatial intelligence } \\
\text { Просторовий інтелект }\end{array}$} \\
\hline & $\begin{array}{c}\text { Boys } \\
\text { Юнаки }\end{array}$ & $\begin{array}{c}\text { Girls } \\
\text { Дівчата }\end{array}$ & $\begin{array}{c}\text { Воуs } \\
\text { Юнаки }\end{array}$ & $\begin{array}{c}\text { Girls } \\
\text { Дівчата }\end{array}$ & $\begin{array}{c}\text { Bоуs } \\
\text { Юнаки }\end{array}$ & $\begin{array}{c}\text { Girls } \\
\text { Дівчата }\end{array}$ \\
\hline $\begin{array}{l}\text { Sum, } \Sigma \\
\text { Сума, } \Sigma\end{array}$ & 2432 & 3102 & 1143 & 1131 & 1294 & 1111 \\
\hline $\begin{array}{l}\text { Mean, Mx } \\
\text { Середні показники, Mx }\end{array}$ & 49.4 & 66.0 & 24.7 & 24.0 & 27.2 & 23.6 \\
\hline $\begin{array}{l}\text { Dispersion, Dx } \\
\text { Дисперсія, Dx }\end{array}$ & 294.7 & 326.2 & 55.3 & 26.2 & 61.6 & 49.2 \\
\hline $\begin{array}{l}\text { Standard Deviation, } \Sigma \mathrm{x} \\
\text { Ст. відхилення, } \Sigma \mathrm{x}\end{array}$ & 17.1 & 18.0 & 7.4 & 5.1 & 7.8 & 7.01 \\
\hline
\end{tabular}

The total sample of high school students and university students was combined and divided into two groups to compare the gender features of intellectual features of girls and boys (girls and boys aged 15-21 years).

Girls had better verbal capacities than boys, according to the results (.01). The boys, on the other hand, had a higher level of spatial development (.05). There were no statistically significant variations in mathematical ability indicators between youths girls and boys (Table 4).

To prove the second and third hypotheses, therelationshipbetweentheindicatorsofemotional evaluation of advertising and intelligence of the respondents were calculated by the method oflinear correlation analysis(Pearson's coefficient) (Tables 5 and 6). The following results were
Значущі відмінності між цими групами виявлено за показниками вербального та математичного інтелекту. Зокрема, студентам 3-го курсу притаманний більш високий рівень розвитку вербальних (.05) та математичних (.05) здібностей. Різниці між показниками рівня розвитку просторового інтелекту в досліджуваних групах не виявлено (табл. 2).

Для порівняння ґендерних особливостей інтелектуальних здібностей дівчат і юнаків загальну вибірку учнів і студентів було об'єднано та поділено на дві групи (дівчата та юнаки у віці 15-21 років).

За результатами отриманих даних, у дівчат краще розвинуті вербальні здібності, ніж у хлопців (.01). Але хлопці мають більш високий рівень розвитку просторових здібностей 
obtained in the age groups of high school students and university students:

- significant direct correlation between verbal intelligence and general emotional evaluation of "Pantene" and "Raiffeisen Bank" commercials and its inverse correlation with "Khilak-forte" advertising (at .05 for high school students and .01 for university students);

- reliable direct correlation of mathematical intelligence and evaluation of the videos "Otryvin" and "Raiffeisen Bank" (.05 for high school students; .01 for university students), "Pantene" (.05 for high school students and university students); in a group of university students, the evaluation
(.05). Статистично значущих відмінностей між показниками математичних здібностей серед дівчат та хлопців юнацького віку не виявлено (табл. 4).

Для доведення другої та третьої гіпотез зв'язки між показниками емоційної оцінки реклами та інтелектом досліджуваних вираховувалися методом лінійного кореляційного аналізу (коефіцієнт Пірсона) (табл. 5 і 6). У вікових групах учнів та студентів було отримано наступні результати:

-значущій прямий зв'язоквербального інтелекту та загальної емоційної оцінки рекламних роликів “Пантін” і “Банк Райфайзен” і його

Table 4. Differences in intelligence indices in boys $(\mathrm{N}=49)$ and girls $(\mathrm{N}=47)$ (according to the method of R. Amthauer) Таблиця 4. Відмінності індексів інтелекту у юнаків (N=49) та дівчат (N=47) (за методикою Р. Амтхауера)

\begin{tabular}{|l|c|c|c|}
\hline \multirow{2}{*}{$\begin{array}{l}\text { Intelligence indicators } \\
\text { Показники інтелекту }\end{array}$} & \multicolumn{2}{|c|}{$\begin{array}{c}\text { Меап indicators } \\
\text { Середні показники }\end{array}$} & \begin{tabular}{c} 
Student's t-test \\
t-критерій Стьюдента \\
\cline { 2 - 4 }
\end{tabular} \\
\cline { 2 - 4 } $\begin{array}{l}\text { Verbal } \\
\text { Вербальний }\end{array}$ & 66.0 & 49.4 & $\mathrm{t}=2.72^{* *}$ \\
\hline $\begin{array}{l}\text { Маthematical } \\
\text { Математичний }\end{array}$ & 24.06 & 24.7 & $\mathrm{t}=1.05$ \\
\hline $\begin{array}{l}\text { Spatial } \\
\text { Просторовий }\end{array}$ & 23.6 & 27.2 & $\mathrm{t}=2.34^{*}$ \\
\hline
\end{tabular}

Note: ${ }^{*} \mathrm{p}<.05 ;{ }^{* *} \mathrm{p}<.01$.

Примітка: ${ }^{*} \mathrm{p}<.05 ;{ }^{* *} \mathrm{p}<.01$.

Table 5. Coefficients of linear correlations of intelligence indices and evaluation of advertising by high school students $(\mathrm{N}=47)$ and university students $(\mathrm{N}=49)$

Таблиця 5. Коефіцієнти лінійних кореляцій індексів інтелекту та оцінювання реклами учнями $(\mathrm{N}=47) \mathrm{i}$ студентами $(\mathrm{N}=49)$

\begin{tabular}{|c|c|c|c|c|c|c|}
\hline \multirow{2}{*}{$\begin{array}{c}\text { Commercial } \\
\text { Рекламний ролик }\end{array}$} & \multicolumn{2}{|c|}{$\begin{array}{c}\text { Verbal intelligence } \\
\text { Вербальний інтелект }\end{array}$} & \multicolumn{2}{|c|}{$\begin{array}{c}\text { Mathematical } \\
\text { intelligence } \\
\text { Математичний інтелект }\end{array}$} & \multicolumn{2}{|c|}{$\begin{array}{c}\text { Spatial intelligence } \\
\text { Просторовий інтелект }\end{array}$} \\
\hline & $\begin{array}{l}\text { High school } \\
\text { students } \\
\text { Учні } \\
\end{array}$ & $\begin{array}{l}\text { University } \\
\text { students } \\
\text { Студенти } \\
\end{array}$ & $\begin{array}{c}\text { High school } \\
\text { students } \\
\text { Учні } \\
\end{array}$ & $\begin{array}{l}\text { University } \\
\text { students } \\
\text { Студенти } \\
\end{array}$ & $\begin{array}{c}\text { High school } \\
\text { students } \\
\text { Учні } \\
\end{array}$ & $\begin{array}{c}\text { University } \\
\text { students } \\
\text { Студенти } \\
\end{array}$ \\
\hline $\begin{array}{l}\text { "Otryvin" } \\
\text { "Отривін" }\end{array}$ & .211 & .241 & $.368^{*}$ & $.398^{* *}$ & $.315^{*}$ & $.297^{*}$ \\
\hline $\begin{array}{l}\text { "Pantene" } \\
\text { "Пантін" }\end{array}$ & $.289 *$ & $.371^{* *}$ & $.263^{*}$ & $.291 *$ & .023 & .140 \\
\hline $\begin{array}{l}\text { "Khilak - forte" } \\
\text { "Хілак - форте" }\end{array}$ & $-.292 *$ & $-.345^{*}$ & .166 & $-.269 *$ & -.209 & .163 \\
\hline "Samsung" & .143 & .013 & -.089 & -.073 & $-.286 *$ & $-.295^{*}$ \\
\hline $\begin{array}{l}\text { “Raiffeisen Bank" } \\
\text { "Банк Райфайзен” }\end{array}$ & $.321^{*}$ & $.367^{* *}$ & $.297^{*}$ & $.373^{* *}$ & .193 & $.265^{*}$ \\
\hline
\end{tabular}

Note: ${ }^{*} p<.05 ;{ }^{* *} p<.01$.

Примітка: ${ }^{*} \mathrm{p}<.05 ;{ }^{* *} \mathrm{p}<.01$. 
Age and gender features of the correlation between the emotional evaluation of commercials and the intelligence indicators of high school and university students of the video "Khilak-forte" was significantly inversely correlated with mathematical intelligence (.05).

- significant correlations of spatial intelligence: direct correlation with the emotional evaluation of the video "Otryvin" and the inverse correlation - with the evaluation of advertising "Samsung" (.05 for high school students and university students); in the group of university students, the evaluation of the "Raiffeisen Bank" video (.05) also significantly correlated with spatial intelligence.

In the gender groups of boys and girls (Table 6), direct correlations between verbal intelligence indicators and the evaluation of "Raiffeisen Bank" (.01) and "Pantene" commercials (.05 and .01, respectively) were obtained; also inverse correlation on the rating of the video "Khilak-forte" (.05). However, only in boys the evaluation of the video "Otryvin" directly correlated with verbal intelligence (.05).

The videos "Otryvin", "Pantene”, and "Raiffeisen Bank" all had a statistically significant direct correlation between mathematical abilities and emotional evaluation (.05 for girls, .01 for boys). The evaluation of the videos "Khilak-forte" and "Samsung" only strongly inversely correlated with mathematical intelligence in the group of girls (.05). In both gender groups, spatial intelligence indicators are directly correlated with the evaluation of the video "Otryvin" (.05), in boys, зворотній зв'язок з рекламою “Хілак-форте” (на рівні .05 у учнів та .01 у студентів);

- достовірний прямий зв'язок математичного інтелекту та оцінки роликів “Отривін” і “Банк Райфазен” (.05 у учнів; .01 у студентів), "Пантін” (.05 у учнів і у студентів); у групі студентів оцінка ролика "Хілак-форте” значуще зворотно корелює з математичним інтелекTOM (.05).

- значущі зв'язки просторового інтелекту: прямий зв'язок з емоційною оцінкою ролику “Отривін" та зворотній - 3 оцінкою реклами “Samsung” (.05 у учнів і у студентів); у групі студентів значуще корелює 3 просторовим інтелектом також оцінка ролику “Банк Райфазен” (.05).

У ґендерних групах юнаків та дівчат (табл. 6) отримані прямі кореляційні зв'язки показників вербального інтелекту з оцінкою рекламних роликів “Банк Райфайзен” (.01) і "Пантін" (.05 та .01 відповідно); також зворотній зв'язок з оцінкою ролику “Хілак-форте” (.05). Однак тільки у юнаків оцінка ролику “Отривін” прямо корелює з вербальним інтелектом (.05).

Отримано статистично достовірні прямі зв'язки математичних здібностей та емоційної оцінки роликів “Отривін”, “Пантін” і “Банк Райфазен” (.05 у дівчат, .01 у хлопців). Тільки у групі дівчат оцінка роликів “Хілак-форте" та "Samsung" значуще зворотно корелює

Table 6. Coefficients of linear correlations of intelligence indices and evaluation of emotional perception of TV commercials by boys $(\mathrm{N}=49)$ and girls $(\mathrm{N}=47)$

\begin{tabular}{|c|c|c|c|c|c|c|}
\hline \multirow{2}{*}{$\begin{array}{c}\text { Name of commercial } \\
\text { Назва ролика }\end{array}$} & \multicolumn{2}{|c|}{$\begin{array}{c}\text { Verbal intelligence } \\
\text { Вербальний інтелект }\end{array}$} & \multicolumn{2}{|c|}{$\begin{array}{l}\text { Mathematical intelligence } \\
\text { Математичний інтелект }\end{array}$} & \multicolumn{2}{|c|}{$\begin{array}{c}\text { Spatial intelligence } \\
\text { Просторовий інтелект }\end{array}$} \\
\hline & $\begin{array}{c}\text { Boys } \\
\text { Юнаки }\end{array}$ & $\begin{array}{c}\text { Girls } \\
\text { Дівчата } \\
\end{array}$ & $\begin{array}{c}\text { Boys } \\
\text { Юнаки }\end{array}$ & $\begin{array}{c}\text { Girls } \\
\text { Дівчата }\end{array}$ & $\begin{array}{c}\text { Boys } \\
\text { Юнаки }\end{array}$ & $\begin{array}{c}\text { Girls } \\
\text { Дівчата }\end{array}$ \\
\hline $\begin{array}{l}\text { "Otryvin" } \\
\text { "Отривін" }\end{array}$ & $.362 *$ & 0,247 & $.372^{* *}$ & $.297 *$ & $.359 *$ & $.316^{*}$ \\
\hline $\begin{array}{l}\text { "Pantene" } \\
\text { "Пантін" }\end{array}$ & $.322 *$ & $.459 * *$ & $.312 *$ & $.282^{*}$ & .023 & .123 \\
\hline $\begin{array}{l}\text { "Khilak - forte" } \\
\text { "Хілак - форте" }\end{array}$ & $-.289 *$ & $-.271^{*}$ & .146 & $-.317^{*}$ & .204 & .098 \\
\hline "Samsung" & -.075 & .034 & -.243 & $-.299 *$ & -.256 & $-.288^{*}$ \\
\hline $\begin{array}{l}\text { "Raiffeisen Bank" } \\
\text { "Банк Райфайзен” }\end{array}$ & $.366^{* *}$ & $.397^{* *}$ & $.371^{* *}$ & $.309 *$ & $.293^{*}$ & .175 \\
\hline
\end{tabular}

Note: ${ }^{*} \mathrm{p}<.05 ;{ }^{* *} \mathrm{p}<.01$.

Примітка: * $\mathrm{p}<.05 ;{ }^{* *} \mathrm{p}<.01$. 
spatial intelligence is directly correlated with the rating of advertising "Raiffeisen Bank" (.05), and in girls, spatial intelligence is inversely correlated with the evaluation of advertising "Khilak-forte" (.05).

\section{Discussion}

We hypothesized according to obtained age and gender differences in intelligence that they could be predictors of affective perception and emotional evaluation of advertising as one of the most powerful objects in the modern world.

Regarding the independent variable "age", in both age groups (adolescence and youths) there were significant correlations between intelligence and emotional evaluations of commercials. However, they are almost similar in groups of high school and university students. Therefore, there is reason to say that there is no significant influence of the age characteristics of intelligence on the perception of television advertising at this age. The development of intelligence as metacognition continues, but its regulatory functions are probably already more stable in the period under study.

It should be noted that the high levels of verbal and mathematical intelligence in both age groups are associated with a positive evaluation of the videos "Pantene" and "Raiffeisen Bank" (direct correlation), as well as a negative evaluation of the video "Khilak-forte". The semantic space of the videos "Pantene" and "Raiffeisen Bank" fascinating for the respondents consists of such features of the SD as "attractive", "interesting", "original", "understandable", "informative". Instead, the semantic space of the commercial "Khilak-forte" is based mainly on the negative characteristics of SD ("boring", "sad", "ugly" and "repulsive").

Mathematical and spatial intelligence in both age groups is associated with the affective dimension to the meaning of the video "Otryvin", which indicates the attractiveness for respondents with high intelligence elements of computer graphics and 3D effects in advertising. Adolescents and young people with high levels of mathematical and spatial intelligence negatively and quite controversially evaluated the advertising of "Samsung": on the one hand, this video is described by them as "uninformative",
3 математичним інтелектом (.05). Показники просторового інтелекту прямо корелюють в обох гендерних групах з оцінкою ролику “Отривін” (.05), у юнаків просторовий інтелект прямо корелює з оцінкою реклами “Банк Райфайзен” (.05), а у дівчат - зворотно з оцінкою реклами “Хілак-форте” (.05).

\section{Дискусія}

Встановлені вікові та гендерні відмінності інтелекту дозволили нам припускати, що вони можуть бути предикторами афективно забарвленого сприймання та емоційної оцінки реклами як одного 3 найбільш впливових об'єктів сучасного світу.

Щодо незалежної змінної "вік”, то в обох вікових групах (підлітки та юнаки) було констатовано достовірні кореляційні зв'язки інтелекту з емоційними оцінками рекламних роликів. Однак, вони є майже подібними в групах учнів та студентів. Тому є підстави говорити про відсутність значного впливу вікових особливостей інтелекту на сприйняття телереклами у цьому віці. Розвиток інтелекту, як метакогніції, триває, але його регулятивні функції у досліджуваний період, ймовірно, вже $\epsilon$ більш сталими.

Зазначимо, що високі показники вербального та математичного інтелекту в обох вікових групах пов'язані з позитивною оцінкою роликів “Пантін” та “Банк Райфайзен” (прямий зв'язок), а також з негативною оцінкою ролика "Хілак-форте". Семантичний простір привабливих для респондентів роликів "Пантін" та "Банк Райфайзен" складають такі ознаки СД, як "привабливий”, “цікавий”, "оригінальний”, “зрозумілий”, “інформативний”. Натомість, семантичний простір рекламного ролика "Хілак-форте" будується переважно на негативних характеристиках СД ("нудний”, “сумний”, “некрасивий” і “відштовхуючий”).

Математичний та просторовий інтелект в обох вікових групах пов'язаний з афективно забарвленим значенням ролика “Отривін”, що свідчить про привабливість для респондентів 3 високим інтелектом елементів комп'ютерної графіки та 3D-ефектів у рекламі. Підлітки і юнаки з високими показниками математичного та просторового інтелекту негативно 


\section{Age and gender features of the correlation between the emotional evaluation of commercials and the intelligence indicators of high school and university students}

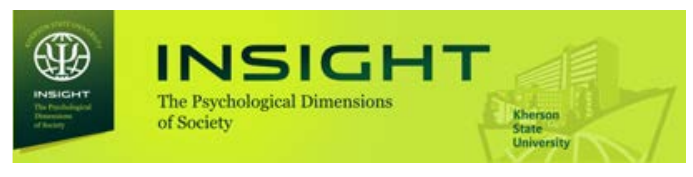

"banal" and "mindless", and on the other - as "understandable", "fast", "non-aggressive".

It's worthy to note that, in most cases, the correlations between intelligence and commercial evaluation are more statistically significant among university students (.01 compared to.05 in high school students), while the correlation direction remains the same. Therefore, we may speak of a gradual increase in the role of intelligence in the perception and evaluation of significant objects in the world.

Regarding the independent variable "gender", the results of statistical analysis show that there are more significant differences in the evaluations of advertising by respondents of different genders. It should be noted that in boys the correlations between intelligence and semantic evaluation of videos are generally more statistically significant, but in girls they are more numerous, in particular, in the data of their group there are more negative correlations.

Thus, for example, boys with a high level of development of verbal intelligence positively evaluate both game music commercials ("Pantene", "Raiffeisen Bank") and commercials, using computer graphics and special effects ("Otryvin"). Girls with a high level of verbal intelligence give positive emotional evaluations only to the first two, without showing much commitment to the use of computer graphics. The differences between boys and girls with high spatial intelligence are that the first appreciate commercials with a playful musical plot ("Raiffeisen Bank") and with the use of computer special effects ("Otryvin"). While the second appreciate only a video with the use of computer special effects ("Otryvin"), which was perceived by girls less positively and received more negative reviews ("sad", "banal", "ugly"). An interesting fact is that girls have significant connections between mathematical intelligence and the evaluation of all five videos. This suggests its regulatory role in the perception of objects in the world around girls, which is more important than verbal or spatial intelligence.

In the sample of boys, all types of intelligence are positively associated with "Otryvin" advertising, which is based on the use of 3D objects and computer graphics. At the same time, in the sample of girls, only girls with high mathematical and spatial i доволі суперечливо оцінили рекламу "Samsung": $з$ одного боку цей ролик охарактеризовано ними як “малоінформативний”, “банальний” i “нерозумний”, а 3 іншого - як "зрозумілий”, “швидкий”, “неагресивний”.

Зазначимо, що у більшості випадків серед студентів кореляційні зв'язки індексів інтелекту та оцінки рекламних роликів $\epsilon$ більш статистично значущими (на рівні .01 порівняно 3.05 у учнів), у той час, як напрямок зв'язку залишається тим самим. Отже, можна говорити про тенденцію помірного посилення ролі інтелекту у сприйманні та оцінці значущих об’єктів світу.

Щодо незалежної змінної "стать", то результати статистичного аналізу демонструють наявність більш суттєвих відмінностей в оцінках реклами у респондентів різної статі. Зазначимо, що у хлопців кореляційні зв'язки інтелекту і семантичної оцінки роликів в цілому більш статистично значущі, але у дівчат їх кількісно більше, зокрема, в даних їх групи встановлено більше негативних кореляційних зв'язків.

Так, наприклад, юнаки 3 високим рівнем розвитку вербального інтелекту позитивно оцінюють як ігрові музичні рекламні ролики ("Пантін”, “Банк Райфайзен”), так і ролики, з використанням комп'ютерної графіки та спецефектів (“Отривін”). Дівчата з високим рівнем розвитку вербального інтелекту віддають позитивні емоційні оцінки лише першим двом, не демонструючи особливої прихильності до використання елементів комп'ютерної графіки. Відмінності між хлопцями і дівчатами з високим просторовим інтелектом полягають у тому, що перші високо оцінюють рекламні ролики з ігровим музичним сюжетом (“Банк Райфайзен”) і з використанням комп'ютерних спецефектів (“Отривін”). Тоді як другі - лише ролик з використанням комп'ютерних спецефектів (“Отривін”), який був сприйнятий дівчатами менш позитивно і отримав більше негативних оцінок ("сумний”, “банальний”, “некрасивий”). Цікавим фактом є наявність значущих зв'язків математичного інтелекту у дівчат з оцінкою всіх п'яти роликів. Це дозволяє припускати, що його регулятивна роль у сприйманні об'єктів оточуючого світу у дівчат $є$ більш значущою порівняно з вербальним чи просторовим інтелектом. 
intelligence gave a positive evaluation of this video. We can assume the influence of the previous socialization of boys (features of upbringing, social stereotypes, etc.), which determines the data obtained. Instead, girls with a high level of mathematical and spatial intelligence, in contrast to boys, significantly negatively evaluate the video "Samsung", which uses the image of the world-famous tennis player M. Sharapova, who symbolically advertises the phone "Samsung" with body movements. Thus, as shown in the study (Spalova \& Bacikova, 2017), the use of advertising featuring stars does not always lead to positive results. According to SD's "true-false" girls with a high level of verbal and mathematical intelligence are more trusting of commercials than boys.

Comparing the results of correlation analysis, we see that in all four studied samples there are mostly statistically significant inverse correlations of verbal, mathematical, spatial intelligence indices with the emotional evaluation of the commercial "Khilakforte" and "Samsung". In the first case, this may be not only because of the characteristics of the respondents themselves (age, gender, individual), but also the content of the product itself, which is the object of advertising ("Khilak-forte" as a laxative). In the second case, it may be either the use of the female body in advertising or the image of a famous person, which may be overloaded with other negative information content. Thus, the fact that boys tend to have a positive perception of celebrities of the opposite gender in advertising has not been confirmed (Phua et al, 2018).

It's worthy to note the presence in all four groups of reliable correlations of indices of mathematical and spatial intelligence with the emotional evaluation of advertising "Otryvin", indices of verbal and mathematical intelligence with advertising "Pantene", as well as direct (positive) correlations of all indices of intelligence with an emotional evaluation of "Raiffeisen Bank" advertising. These sufficiently stable correlations, which take place regardless of age and gender, show that there are probably some universal patterns of evaluation of videos that are common to all respondents.

\section{Conclusions}

The idea that intelligence is a core quality of not only cognitive but also holistic personal
У вибірковій сукупності хлопців всі типи інтелекту пов'язані позитивно 3 рекламою “Отривін”, яка базується на використанні 3D об’єктів і комп’ютерної графіки. Водночас у вибірці дівчат позитивну оцінку цьому ролику надали тільки дівчата з високим математичним та просторовим інтелектом. Можна припускати вплив попередньої соціалізації хлопців (особливості виховання, соціальні стереотипи тощо), що зумовлює отримані дані. Натомість дівчата з високим рівнем математичного та просторового інтелекту, на відміну від хлопців, значуще негативно оцінюють ролик "Samsung", у якому використовується образ всесвітньо відомої тенісистки М. Шарапової, яка символічно, за допомогою рухів тіла рекламує телефон "Samsung". Отже, як було показано в дослідженні (Spalova \& Bacikova, 2017), використання реклами за участю зірок не завжди призводить до позитивних результатів. Згідно оцінки СД “правдивий-неправдивий" дівчата з високим рівнем вербального та математичного інтелекту більш довірливо ставляться до рекламних роликів, ніж хлопці.

Порівнюючи результати кореляційного аналізу, бачимо, що в усіх чотирьох досліджуваних вибірках наявні переважно статистично достовірні зворотні кореляційні зв'язки індексів вербального, математичного, просторового інтелекту з емоційною оцінкою рекламного ролику "Хілак-форте" та "Samsung". У першому випадку це може бути зумовлено не тільки особливостями самих досліджуваних (віковими, гендерними, індивідуальними), але і змістом самого продукту, який $є$ об'єктом реклами ("Хілак-форте" як проносний засіб). У другому випадку мова може йти або про використання жіночого тіла в рекламі, або про образ відомої людини, який, можливо, перевантажений іншим негативним інформаційним змістом. Не підтвердився таким чином факт, що юнаки, як правило, позитивно сприймають знаменитостей протилежної статі у рекламі (Phua et al, 2018).

Зазначимо, також наявність у всіх чотирьох групах достовірних зв'язків індексів математичного і просторового інтелекту з емоційною оцінкою реклами “Отривін”, індексів вербального і математичного інтелекту з рекламою “Пантін”, а також прямі (позитивні) кореляційні зв'язки всіх індексів інтелекту з емоційною оцінкою реклами "Банк Райфазен". Ці доволі сталі зв'язки, які мають місце незалежно від вікових та гендерних особливостей, 
Age and gender features of the correlation between the emotional evaluation of commercials and the intelligence indicators of high school and university students

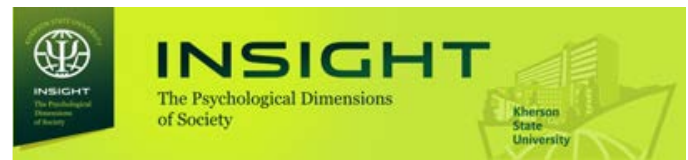

development is gaining ground in modern psychology. The role of intelligence was demonstrated by the correlations between the intellectual abilities of adolescents and young people of different genders and the importance of commercials for them.

The results of the diagnosis revealed significant age and gender differences in verbal, mathematical, and spatial intelligence of the studied groups, as well as significant correlations between the emotional evaluation of advertising with the gender characteristics of the intelligence of the respondents. Thus, the first and third hypotheses were confirmed, while the second only partially.

The participants of both age samples showed almost similar results. In particular, the high intelligence indices of the respondents are related to the positive evaluation of the commercials "Pantene", "Otryvin" and "Raiffeisen Bank", and the negative evaluation of the commercials "Khilak-forte" and "Samsung". There are significant differences in the evaluations of advertising between respondents of different genders. Thus, the use of computer graphics in advertising is more interesting for boys, and the use of a sports star in advertising, which uses its own body, causes a more negative reaction in girls. Boys with a high level of intelligence are more positive about commercials using computer graphics and special effects ("Otryvin"), and girls - with the participation of actors ("Raiffeisen Bank"). The obtained results showed that the gender characteristics of the respondents' intelligence are more significant predictor of emotional evaluation of advertising in adolescence and youths than the age characteristics of intelligence development.

Respondents with a high level of intellectual development, regardless of their age or gender, appreciate music videos with actors and the use of computer graphics. The most attractive, and therefore more effective, is advertising, which contains a "behavioral" and emotionally colored component, which features people (actors) and shows the different ways of their behavior in the process of unfolding the plot. An example of this is the promotional video "Raiffeisen Bank", which received the highest positive emotional ratings, i.e. was the closest to показують, що є ймовірно певні універсальні закономірності оцінки роликів, які $\epsilon$ спільними для всіх респондентів.

\section{Висновки}

У сучасній психології набуває все більшого підтвердження думка, що інтелект $\epsilon$ стрижневою якістю не тільки когнітивного, а й цілісного особистісного розвитку. Продемонструвати цю роль інтелекту дозволили встановлені у дослідженні зв'язки інтелектуальних здібностей підлітків та юнаків різної статі з афективно забарвленим для них значенням рекламних роликів.

За результатами діагностики було констатовано значущі вікові та гендерні відмінності вербального, математичного та просторового інтелекту досліджуваних груп, а також значущі кореляційні взаємозв'язки емоційної оцінки реклами 3 гендерними особливостями інтелекту респондентів. Таким чином, перша та третя гіпотези були підтверджені, у той же час друга - лише частково.

Досліджувані обох вікових вибірок показали майже подібні результати. Зокрема, високі індекси інтелекту респондентів пов'язані з позитивною оцінкою рекламних роликів "Пантін", “Отривін" та "Банк Райфазен”, та негативною оцінкою рекламних роликів “Хілак-Форте" та "Samsung". Встановлено суттєві відмінності в оцінках реклами між респондентами різної статі. Так, використання у рекламі комп'ютерної графіки є більш цікавим для хлопців, а використання у рекламі зірки спорту, яка використовує власне тіло, викликає більш негативну реакцію у дівчат. Хлопці з високим рівнем інтелекту більш позитивно сприймають рекламні ролики з використанням комп'ютерної графіки та спецефектів (“Отривін”), а дівчата - за участі акторів (“Банк Райфайзен”). Отримані результати показали, що гендерні особливості інтелекту респондентів $\epsilon$ більш значущим предиктором емоційної оцінки реклами у підлітковому та юнацькому віці, ніж вікові особливості розвитку інтелекту.

Досліджувані з високим рівнем розвитку інтелектуальних здібностей, незалежно від їх вікових чи гендерних особливостей, високо оцінюють музичні ролики з участю акторів та використанням комп'ютерної графіки. Найбільш привабливою, отже і більш ефективною $€$ реклама, яка містить "поведінковий" 
the perfect video in all groups. Thus, the emotional evaluation of advertising is mediated not only by the intelligence but also by the person, their implicit theory of the world, themselves, others. This area of research is the prospect of our further experimental explorations.

\section{References}

Anan'ev, B. G. (1977). O problemah sovremennogo chelovekoznaniya [On the problems of modern human science]. Moscow: Nauka.

Akimova, M. K. (1999). Intellekt kak dinamicheskiy komponent $\mathrm{v}$ strukture sposobnostey: avtoref.dis. na soisk. nauk. stepeni dokt. psihol. nauk [Intelligence as a dynamic component in the structure of abilities]. Avtoref. dis. na soisk. nauk. stepeni dokt. psihol. nauk: 19.00.01. - Extended abstract of Doctor's thesis. Moscow.

Amthauer, R., Brocke, B., Liepmann, D., \& Beauducel, A. (2001). Intelligenz-Struktur-Test 2000. R. Göttingen: Hogrefe. DOI: 10.1026//1617-6391.1.1.50

Brand C.R., Egan V., \& Deary I.Y. (1991). General intelligence and personality: No relation? In Dc. Detterman (Ed) Current topics in human intelligence. New York.

Breit, M., Brunner, M., \& Preckel, F. (2020). General intelligence and specific cognitive abilities in adolescence: Tests of age differentiation, ability differentiation, and their interaction in two large samples. Dev Psychol, 56(2), 364-384. DOI: $10.1037 /$ dev0000876

Drozd, L. V., \& Bystrova, Yu. O. (2020). Features of communication of adolescents with intellectual disabilities in the interpersonal relations. Insight: the psychological dimensions of society, 3, 123-133. DOI: $10.32999 / 2663-970 X / 2020-3-9$

Di Paolo, E. A., \& Thompson, E. (2014). The enactive approach. The Routledge Handbook of Embodied Cognition / L. Shapiro (ed.). London; New York: Routledge Press.

Holodnaya, M. A. (2003). Kognitivnyie stili. O prirode individualnogo uma. [Cognitive Styles. On the nature of the individual mind]. Moscow: PER SE.

Eysenck, H. L. (1996). Genius: the natural history of creativity. Cambridge: Cambridge University Press.

Ivanova, V. P. (2013). Razvitie intellekta kak osnovanie lichnostno-professionalnogo stanovleniya studentov: avtoref. dis. na soisk. nauk. stepeni dokt. psihol. nauk: 19.00.07. [The development of intelligence as the basis of the personal and professional development of students]. Avtoref. dis. na soisk. nauk. stepeni dokt. psihol. nauk: 19.00.01. Extended abstract of Doctor's thesis. Moscow.

Joe, Phua, Jhih-Syuan, (Elaine) Lin, \& Dong Jae Lim (2018). Understanding Consumer Engagement with Celebrity-Endorsed E-Cigarette Advertising on Instagram. Computers in Human Behavior та емоційно забарвлений компонент, у якій фігурують люди (актори) та показані різноманітні способи їхньої поведінки у процесі розгортання сюжету. Прикладом цього $\epsilon$ рекламний відеоролик “Банк Райфазен”, який отримав найвищі позитивні емоційні оцінки, тобто виявився найближчим до ідеального ролика в усіх досліджуваних групах. Отже, емоційне оцінювання реклами опосередковане не тільки інтелектом, але й особистістю, iї імпліцитною теорією світу, себе, інших. Цей напрямок дослідження $€$ перспективою наших подальших експериментальних розвідок.

\section{Список використаних джерел}

Ананьев Б. Г. О проблемах современного человекознания. Москва: Наука, 1977. 379 с.

Акимова М. К. Интеллект как динамический компонент в структуре способностей: автореф. дис. на соиск. наук. степени докт. психол. наук: 19.00.01. Москва, 1999. 21 с.

Amthauer R., Brocke, B., Liepmann, D., Beauducel, A. Intelligenz-Struktur-Test 2000. R. Göttingen: Hogrefe. 2001. DOI: 10.1026//1617-6391.1.1.50

Brand C. R., Egan V., Deary I. Y. General intelligence and personality: No relation? In Dc. Detterman (Ed) Current topics in human intelligence. N.Y., 1991.

Breit M, Brunner M, Preckel F. General intelligence and specific cognitive abilities in adolescence: Tests of age differentiation, ability differentiation, and their interaction in two large samples. Dev Psychol. 2020 Feb;56(2):364-384. doi: 10.1037/ dev0000876.

Drozd L. V., Bystrova Yu. O. Features of communication of adolescents with intellectual disabilities in the interpersonal relations. Insight: the psychological dimensions of society. 2020. № 3. P. 123-133. DOI: $10.32999 / 2663-970 X / 2020-3-9$

Di Paolo, E. A., Thompson, E. The enactive approach. The Routledge Handbook of Embodied Cognition / L. Shapiro (ed.). 2014. London; New York: Routledge Press. 68-78.

Холодная М. А. Когнитивные стили. О природе индивидуального ума. Москва: ПЕР СЭ, 2002.

Eysenck H.L. Genius: the natural history of creativity. Cambridge: Cambridge University Press, 1996.

Иванова В.П. Развитие интеллекта как основание личностно-профессионального становления студентов: автореф. дис. на соиск. наук. степени докт. психол. наук: 19.00.07. Москва, 2013. 21 с.

Joe, Phua, Jhih-Syuan, (Elaine) Lin, Dong Jae Lim Understanding Consumer Engagement with Celebrity-Endorsed E-Cigarette Advertising on Instagram. Computers in Human Behavior 2018. [Electronic resource]. URL: https://www.researchgate. net/publication / 323311884 Understanding_Consumer_Engagement_with_Celebrity-Endorsed_E Cigarette_Advertising_on_Instagram. DOI: $10.1177 / 1359105317693912$

Kurt F. Geisinger Empirical Considerations on Intelligence Testing and Models of Intelligence: Updates

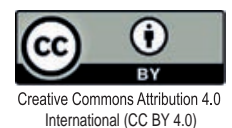


Age and gender features of the correlation between the emotional evaluation of commercials and the intelligence indicators of high school and university students

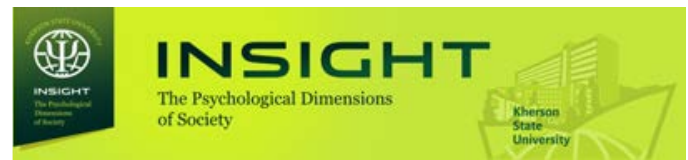

[Electronic resource]. URL: https://www.researchgate. net/publication/323311884_Understanding_ Consumer_Engagement_with_Celebrity-Endorsed_ ECigarette_Advertising_on_Instagram. DOI: $10.1177 / 1359105317693912$

Kurt, F. Geisinger (2019). Empirical Considerations on Intelligence Testing and Models of Intelligence: Updates for Educational Measurement Professionals, Applied Measurement in Education, 32(3), 193-197. DOI: 10.1080/08957347.2019.1619564

Latvala, A., Kuja-Halkola, R., D’Onofrio, B. M., Larsson, H., \& Lichtenstein, P. (2016). Cognitive ability and risk for substance misuse in men: genetic and environmental correlations in a longitudinal nationwide family study. Addiction, 111(10), 1814-1822. DOI: $10.1111 /$ add.13440

Meily, R., \& Meili, R. (1981). Structur der Intelligenz: Factorenanalitische und denkpsychologische Unter-suchungen. Bern.

Mollon, J., David, A. S., Zammit, S., Lewis, G., \& Reichenberg, A. (2018). Course of Cognitive Development from Infancy to Early Adulthood in the Psychosis Spectrum. JAMA Psychiatry, 06510. DOI: $10.1001 /$ jamapsychiatry.2017.4327

Panksepp, J. (2000). The neuro-evolutionary cusp between emotions and cognitions: implications for understanding consciousness and the emergence of unified mind science. Consciousness and Emotion, 1, 23-34.

Plichtová, J. (2002). Metódy sociálnej psychológie zblízka. Kvalitatívne a kvantitatívne skúmanie sociálnych reprezentácií. Bratislava, Média.

Ponomarev, Ya. A. (1983). Fazyi tvorcheskogo protsessa. Issledovanie problem psihologii tvorchestva [Phases of the creative process. Research into the problems of the psychology of creativity]. Moskva-Moscow: Nauka.

Rubinshtejn, S. L. (1999). Osnovyi obschey psihologii [Fundamentals of General Psychology]. SPb.: Piter.

Rusalov, V. M., \& Dudin, C. I. (1995). Temperament i intellekt: obschie i spetsificheskie faktoryi razvitiya [Temperament and intelligence: general and specific developmental factors]. Psihologicheskiy zhurnal. - Psychological journal, 16 (5), 12-23.

Shamne, A., Dotsevych, T., \& Akimova, A. (2019). PsihosemantichnI osoblivostI spriynyattya reklamnih vIdeorolikIv [Psychosemantic Peculiarities of Promotional Videos Perception]. PSIHOLINGVISTIKA - PSYCHOLINGUISTICS, 25(1), 384-408. DOI: 10.31470/2309-1797-2019-25-1-384-408

Smul'son, M. L. (2003). Psykholohiia rozvytku intelektu [Psychology of intellect development]. Kyiv-Kyiv: Nora-Druk.

Spalova, L., \& Bacikova, Z. (2017). Celebrities in social advertisement: psychosomatic perspective. Economic and Social Development: Book of Proceedings. Prague.

Sternberg, R. J. (1988). The triarchic mind: A new theory of human intelligence. New York: Viking Penguin. for Educational Measurement Professionals, Applied Measurement in Education, 2019. 32:3, 193-197, DOI: $10.1080 / 08957347.2019 .1619564$

Latvala A, Kuja-Halkola R, D’Onofrio BM, Larsson H, \& Lichtenstein P. Cognitive ability and risk for substance misuse in men: genetic and environmental correlations in a longitudinal nation-wide family study.2016. Addiction, 111(10), 1814-1822. DOI: 10.1111 /add.13440

Meily R. Meili R. Structur der Intelligenz: Factorenanalitische und denkpsychologische Unter-suchungen. Bern, 1981.

Mollon J, David AS, Zammit S, Lewis G, \& Reichenberg A. Course of Cognitive Development from Infancy to Early Adulthood in the Psychosis Spectrum. JAMA Psychiatry, 2018. 06510. DOI: 10.1001/jamapsychiatry.2017.4327

Panksepp J. The neuro-evolutionary cusp between emotions and cognitions: implications for understanding consciousness and the emergence of unified mind science. Consciousness and Emotion. 2000. 1. 17-56.

Plichtová J. Metódy sociálnej psychológie zblízka. Kvalitatívne a kvantitatívne skúmanie sociálnych reprezentácií. Bratislava, Média. 2002. 350 s.

Пономарев Я. А. Фазы творческого процесса. Исследование проблем психологии творчества. Под ред. Я. А. Пономарева. Москва: Наука, 1983. С. $5-26$.

Рубинштейн С. Л. Основы общей психологии. СПб.: Питер, 1999, 720 с.

Русалов В. М., Дудин С. И. Темперамент и интеллект: общие и специфические факторы развития. Психологический журнал. 1995. № 16(5). С. 12-23.

Шамне А., Доцевич Т., Акімова А. Психосемантичні особливості сприйняття рекламних відеороликів. ПСИХОЛІНГВІСТИКА. 2019. 25(1). С. 384-408. https://doi.org/10.31470/23091797-2019-25-1-384-408

Смульсон М. Л. Психологія розвитку інтелекту. Київ: Нора-Друк, 2003. 298 с.

Spalova L., Bacikova Z. Celebrities in social advertisement: psychosomatic perspective. Economic and Social Development: Book of Proceedings. Prague. 2017. 392-396

Sternberg R. J. (1988). The triarchic mind: A new theory of human intelligence. New York: Viking Penguin. $354 \mathrm{p}$.

Vorobyova, O. P. 'Haunted by ambiguities' revisited: in search of a metamethod for literary text disambiguation. Lege artis. Language yesterday, today, tomorrow. The Journal of University of SS Cyril and Methodius in Trnava. Warsaw: De Gruyter Open, 2017, vol. II (1), June 2017. P. 428-496. DOI: 10.1515/lart-2017-0011 ISSN 2453-8035

Яковлева С. Д. Індивідуалізація і диференціація в процесі навчання учнів 3 порушеним інтелектом. Iнсайт: психологічні виміри суспільства. 2019. № 1. C.110-116. DOI: 10.32999/2663-970X/2019-1-17

Zlatev J. Turning back to experience. Cognitive Linguistics via phenomenology. Cognitive Linguistics. 2016. № 27(4). 559-572. DOI: 10.1515/cog-2016-0057 